\title{
Aspects of digitalization of the management system in the course of implementation of housing investment and housing projects
}

\section{Аспекты цифровизации системы управления при реализации жилищно- инвестиционных и жилищных проектов}

Received: April 12, 2021
Written by:

Arkadij Larionov?

https://orcid.org/0000-0001-9706-5131

\begin{abstract}
This article aims to show how the implementation of the Unified Information Platform (UIP) significantly reduces the construction time during the organization of housing and investment construction. In the article, the author also considers important aspects of the digitalization of construction production. The methodological design involves the method of sociological analysis, the method of expert assessments with subsequent statistical analysis of the data obtained as a result of the questionnaire, the method of mathematical modeling, and comparison. The results of the study made it possible to show that the Unified Information Platform raises the efficiency of relationships between participants in urban planning activities; reduces the total construction period of the facility by $12 \%$ (153 days); significantly decreases the cost of construction; the functionality of the Unified Information Platform allows to create a streamlined work process and establish timely control over the performance of work; the absence of such systems or only their local variants noticeably lose in efficiency; the introduction of the Unified Information Platform makes it possible, through electronic interaction, to control the vested interests of corporations and not allow the techno-structure represented by government officials to be subordinated; the use of information technology guarantees maximum efficiency and productivity while minimizing production costs.
\end{abstract}

Keywords: Unified information platform, housing investment project, engineering, construction, digitalization.

\begin{abstract}
Аннотация
Цель данной статьи заключается в том, чтобы показать, каким образом внедрение Единой информационной платформы в организацию жилищно-инвестиционного строительства (ЕИП) существенно сокращает сроки строительства. В статье автор рассматривает также важные аспекты цифровизации строительного производства. Методологическая разработка включает метод социологического анализа, метод экспертных оценок с последующим статистическим анализом данных, полученных в результате анкетирования, метод математического моделирования, и сравнения. Результаты исследования позволили показать, что Единая информационная платформа повышает эффективность взаимоотношений между участниками градостроительной деятельности; сокращает общий срок строительства объекта на $12 \%$ (153 дня); существенно уменьшает стоимость строительства; функциональные возможности Единой информационной платформы позволяют создать отлаженный процесс производства работ и наладить своевременный контроль выполнения работ; отсутствие подобных систем или только локальные их варианты заметно проигрывают по эффективности; внедрение единой информационной системы дает возможность через электронное взаимодействие контролировать корыстные интересы корпораций и не позволять подчинять себе техно-структуру, представленную государственными чиновниками; использование информационных технологий гарантирует максимальную эффективность и производительность в условиях минимизации производственных издержек.
\end{abstract}

Ключевые слова: Единая информационная платформа, жилищно-инвестиционный проект, инжиниринг, строительство, цифровизация.

\footnotetext{
${ }^{7}$ Prof., DSc, National Research University - Moscow State University of Civil Engineering, Russia.
} 


\section{Introduction}

The development of the construction industry largely depends on the scale of infrastructure services provision in developed territories. Due to the complexity, uncertainty, and volatility of resource provision and volatility of the technological, social and economic environment, business functions and economic life must increasingly rely on well-thought-out strategy, managerial capabilities, and predictable financial factors. However, recent experience in organizing capital construction shows that the future is becoming more difficult to predict, making it very difficult to predict prospects and likely achievements (Smirnova, 2020, 2021). That is why digitalization of construction is of current interest (Huovinen, 2019). The introduction of information technology helps to identify the shortcomings of existing digital platforms and ensure the development of technical software systems that guarantee maximum efficiency and productivity while minimizing production costs (Ottaviano et al, 2018).

The study of foreign experience (primarily Singapore) made us think about the Unified Information Platform project for the interaction of all construction participants in Moscow and the Moscow Region (Rajan, 2003). From the point of view of the efficiency and productivity of digital complexes, an information platform is needed that would imply a universal access code and would allow structuring segmental information in all organizations participating in the construction industry: among customers, designers, general contractors, subcontractors, in non-profit organizations and government departments, and thus, it would introduce elements of analysis and visualization into the control process, and a reliable method of data processing. All this will create a well-functioning work process by contractors and timely control of work performance by the customer/technical customer and government departments.

\section{Literature Review}

Many researchers considered the unrestrained market as a tool that controls the ability of the construction business to meet the needs and preferences of consumers as a prerequisite for optimizing the management of a centralized economy and as the main regulator of economic proportions. Such researchers recognized the possibility of including the market as a whole in a centralized economy as A. Lerner (1970), A. Pigou (1999), H. Dickinson (1971),
M. Lieberman and R. Hall (2000). They believed that the efficiency of using industrial resources in a centralized economy would be much higher if its mechanism were built on the principles of free competition with the inclusion of market factors to determine the strategic proportions in the national economy (e.g., Lieberman and Hall, 2000).

On the other hand, whether the consumer society provides sufficient strategic funding for public needs and, particularly, for construction infrastructure in Russia; the answer to this question is obvious: private investors are mainly concerned with business issues and market benefits. Such problems as evaluating the effectiveness of a Unified Information Platform implementation in construction organizations, qualitatively updating the calendar schedules for the implementation of housing investment and construction projects, implementing an effective and correct reduction in the implementation terms of planned projects remain mostly outside the field of vision of business structures. Although all major construction corporations and giants compose and analyze different medium and long term scenarios, use different models for studying the capital investment portfolio and resort to the opinion of qualified experts, the corporate vision of the future is still superficial and depends on profit and expansion from outside (Ansoff, 1977, 1995). According to Galbraith (1988, 1997), in such a way, the conditions for inequality in obtaining profit are created since the planned corporate subsystem uses the structure of a market economy consisting of small firms and small companies (Agstner and Mascheroni, 2020; Sterman, 2000).

Management policies pursued by the construction giants in Moscow and the Moscow Region are aimed at regulation through intensive government funding of market actors, their wellorganized control, and a flexible system of corrective actions. In the era of dynamic strategic management, the distinction between "private" and "public" segments of the economy can be neglected (Ansoff, 1980, 1985, 1987). The essence of creating the Unified Information Platform for project management of engineering and construction infrastructures is explained precisely in the above context.

For example, the main attention of the government of the Moscow Region in the construction industry is focused on quality assurance and development of housing 
construction. For this, regional programs are being developed to increase the scope of commissioning of apartment buildings and improve the living conditions of the population. Significant attention in these programs is paid to the introduction of innovations as one of the priority areas for developing the construction industry. From the point of view of the authors, the task of introducing a unified software package into the sphere of management is not just the use of innovative solutions, but the fact that it would contain the negative influence of market actors, while at the same time highlighting the request for the effective implementation of state programs. According to Ansoff (2007), the national economy should more and more show the political or the so-called "network" function of the state-supported forecast, which forms the structure, proportions, trends, and rates of economic development on a long-term sustainable basis (Hernandez and Menon, 2021). Gray and Larson (2008) point out the need for management strategies for a business project and define the characteristics of the transition to this critical form of improving the economic efficiency of manufacturing organizations and structural conversion in the context of comprehensive scientific and technological progress (Voronkova et al., 2020). These are the stages of development, including the integration of the organization's project strategy; plan of the project goal; development of a project plan; management of risks; reduction of the project implementation time; planned resource management; leadership and management of the project team; partnership for design; modern trends in project management (Lo and Liao, 2021).

There is another important advantage from introducing the Unified Information Platform, which is little talked. The goals of digitalization of the construction industry are: reducing the cost of project implementation and operation, the ability to adapt to changes in the development of the industry; functionality, completeness, and the possibility of integration with other managerial structures (for example, numerous government departments and business entities).

The decisive factor in the strategic information management of construction is technological progress, universal but often destructive in nature, the innovations of which replace the old economic model (Schumpeter, 2002, 2013, 2019). It should be emphasized that innovations have led to organizational and planning efforts that are based on certain theoretical principles (Szostak and Boughzala, 2021). The use of theoretical methods in fundamental research is smoothly combined with the introduction of methods that can be directly used to produce goods and provide services. Scientific and technical research is carried out on a planned basis as it is carried out using a proven methodology and is in line with predetermined goals. This technological evolution directly affects the policy of goods supply and directs companies and corporations through the "filter" of unified information management (Lambin et al., 2007; Gary et al., 2017).

The problem is that the economic model is often viewed as a set of immutable existing structures. To this day, researchers are still preoccupied with the competition that takes place within unchanging conditions, particularly permanent means of production and forms of organization. However, in reality, there is the competition of a different type, based on the discovery of new technologies, new sources of raw materials, and new types of organizations (for example, large corporations-giants) (McWilliams and Siegel, 2001). This competition drastically lowers the cost and improves the construction quality, which turns into a complete bankruptcy of existing medium and small companies. This is exactly what is called the "creative destruction" of the structures and institutions of capitalism that is undermining competition and weakening the human factor in entrepreneurship (Schumpeter, 2013).

The following should be noted here. The American economist Ciscel $(1984,2005)$ defined the planning system concept as a replacement for market theory. As a result of "creative destruction" in mature corporations and the planning system of the 21-st century, power and management have shifted from the owners to a techno-structure of engineers and technicians who are not owners (Ciscel, 2001). According to Ciscel (1984), the technical structure is a social class whose position in the economy is determined by its participation in making strategic decisions; this class controls the property but is not required to own it.

In this regard, it is safe to say that the fate of any strategic decision lies in the hands of the technostructure (Reinhardt et al., 2008). In an age of uncertainty, the technostructure of large corporations is strongly tempted to get the best of the technostructure presented by government officials and take advantage of strategic planning to achieve their selfish lucrative goals (Claassen, 2021). It should be borne in mind that in all markets, a developed corporation seeks to protect 


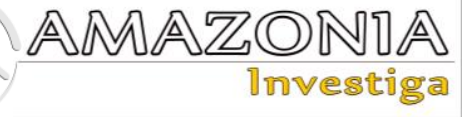

itself from risks and uncertainties, thus striving for solid profits and an exceptional and reliable position in the political and economic environment (Stockhammer, 2006).

Thus, it is necessary to indicate that any firm or corporation is involved in the struggle for profit and acts as an element of private relations since, as an organization, it is functioning in a competitive environment (Bernhagen, 2007). In other words, it participates in the struggle for profit to achieve its goals, neglecting the public interest (Reinhardt and Stavins, 2010). In many aspects, the dynamics and efficiency of an organization's development are determined by the levels of interaction with other organizations and intra-organizational processes. The desire for profit (transition from one level to another) encourages market competitors to introduce innovations, offer new products and services, and actively promote their products on the market. As noted by Schumpeter (2013), the behavior of an innovative entrepreneur is motivated, first of all, not only by monetary profit, but by the desire to gain power and prestige and, thus, to create their own "private kingdom" (Altman, 1999, 2017; Tolstenko et al., 2019). From this point of view, the introduction of the Unified Information Platform makes it possible, through electronic interaction, to control the venal interests of corporations and not allow them to subjugate techno-structure represented by government officials (Aguilera, 2005) (Figure 1).

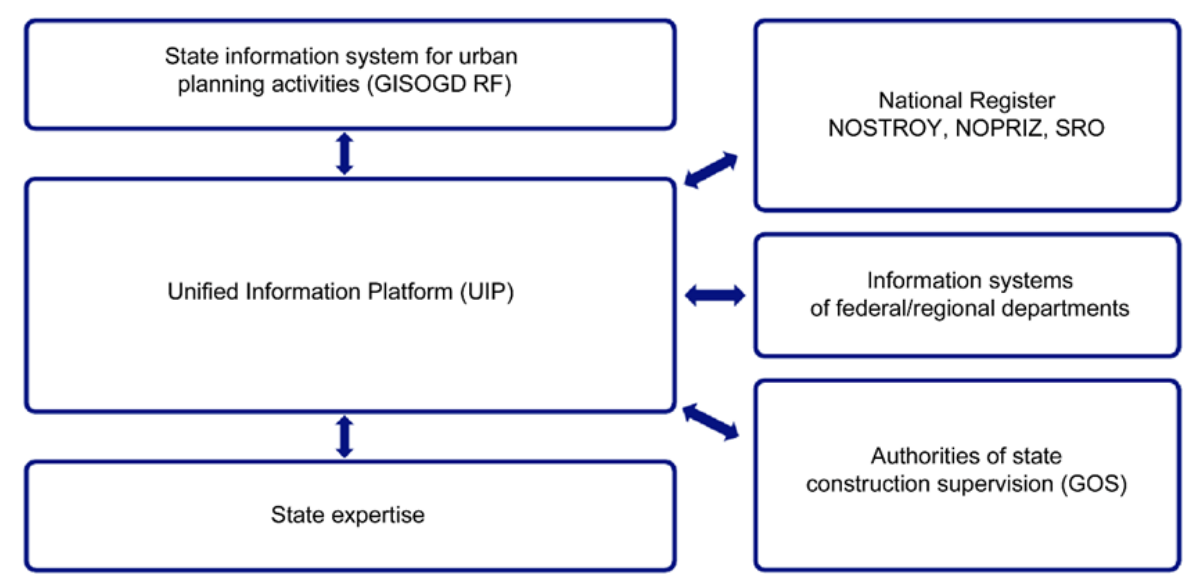

Figure 1. The general structure of integration of various systems (self-regulatory organizations (SRO), National Association of Surveyors and Designers (NOPRIZ), National Association of Builders (NOSTROY). Source: the author

\section{Methodology}

To assess the effectiveness of the implementation of the UIP, the method of expert assessments was used, followed by statistical analysis of the data obtained as a result of the questionnaire (see Fig. 2 and 3).

Dear expert:

In order to determine the terms of an investment and construction project for a multi-storey residential building ( 25 floors, frame-panel, with a total area of $16000 \mathrm{~m}^{2}$ ) I request you to provide the average terms (in days) for the stages presented based on your experience in the implementation of similar projects.

\begin{tabular}{|c|c|c|c|c|c|c|c|c|c|c|c|c|c|}
\hline No. & Description/Stage of the project & 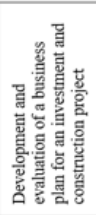 & 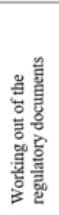 & 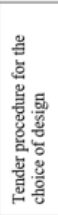 & 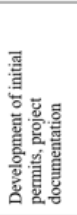 & 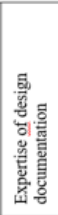 & 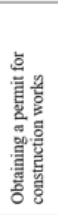 & 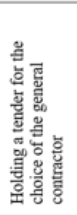 & 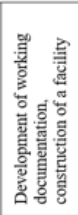 & 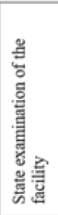 & 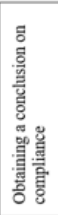 & 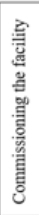 & 형 \\
\hline 1 & $\begin{array}{l}\text { Interaction of participants in urban } \\
\text { planning activities according to the } \\
\text { existing procedure not using platforms }\end{array}$ & & & & & & & & & & & & \\
\hline 2 & $\begin{array}{l}\text { Interaction of participants in urban } \\
\text { planning activities according to the } \\
\text { existing procedure using local } \\
\text { information platforms }\end{array}$ & & & & & & & & & & & & \\
\hline 3 & $\begin{array}{l}\text { Interaction of participants in urban } \\
\text { planning activities on the Unified } \\
\text { Information Platform }\end{array}$ & & & & & & & & & & & & \\
\hline
\end{tabular}

Figure 2. The Questionnaire proposed to experts. Source: the autor. 


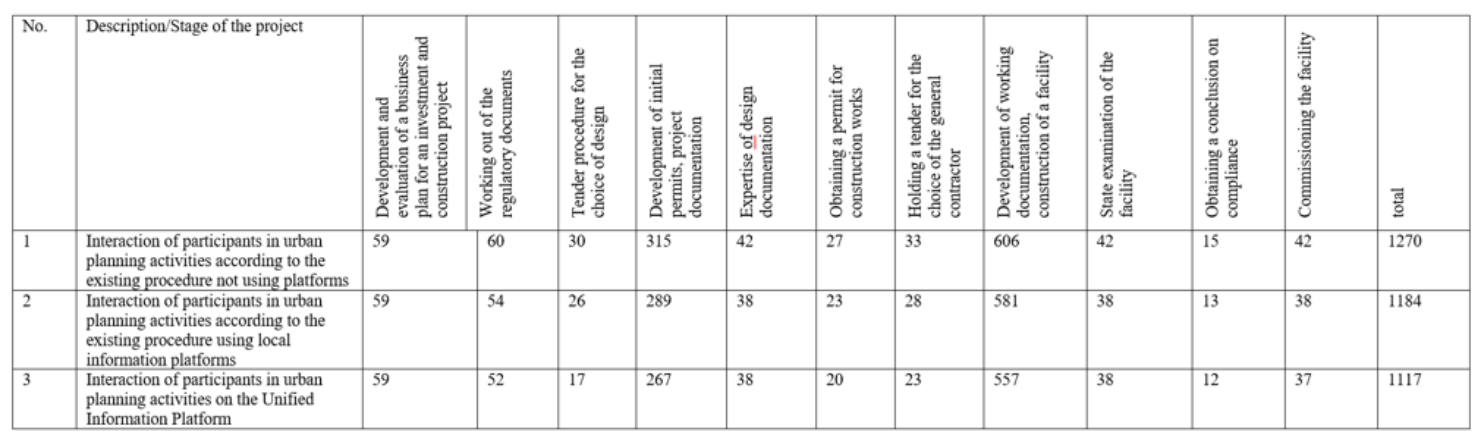

Figure 3. The mean values of expert data. Source: the autor.

The time of implementation of the investment and construction project for a multi-storey residential building was adopted as the main criterion for evaluation.

The survey of experts was carried out using the remote questionnaire method. The answers to the list of questions were the initial empirical data for generalizations and conclusions. In the process of developing the questionnaire, a generalized characteristic of the expert and his most important qualities were formulated.
At the next stage, mathematical modeling of implementing the investment and construction project (ICP) was carried out. A survey of experts was conducted using the method of remote questioning. Having accepted the average error of $10 \%$ and the probability value $(1-\alpha)=0.95$, the required number of participants was obtained with a known error of representativeness not exceeding 5\%, which amounted to at least 96 experts (Table 1).

Table 1.

Determination of the number of experts depending on the error of the mean and the probability coefficient. Source: the author.

\begin{tabular}{llllllllllllllll}
\hline \multirow{2}{*}{ Probability } & \multicolumn{1}{l}{ Error of the mean, \% } & $\mathbf{1}$ & $\mathbf{6}$ & $\mathbf{8}$ & $\mathbf{1 0}$ & $\mathbf{1 2}$ & $\mathbf{1 4}$ & $\mathbf{1 6}$ & $\mathbf{1 8}$ & $\mathbf{2 0}$ & $\mathbf{2 2}$ & $\mathbf{2 4}$ & $\mathbf{2 6}$ & $\mathbf{2 8}$ & $\mathbf{3 0}$ \\
$\mathbf{0 . 6}$ & 441 & 110 & 49 & 28 & 18 & 12 & 9 & 7 & 5 & 4 & 4 & 3 & 3 & 2 & 2 \\
$\mathbf{0 . 7}$ & 663 & 166 & 74 & 41 & 27 & 18 & 14 & 10 & 8 & 7 & 5 & 5 & 4 & 3 & 3 \\
$\mathbf{0 . 7 5}$ & 827 & 207 & 92 & 52 & 33 & 23 & 17 & 13 & 10 & 8 & 7 & 6 & 5 & 4 & 4 \\
$\mathbf{0 . 8}$ & 1040 & 260 & 116 & 65 & 42 & 29 & 21 & 16 & 13 & 10 & 9 & 7 & 6 & 5 & 5 \\
$\mathbf{0 . 8 5}$ & 1296 & 324 & 144 & 81 & 52 & 36 & 26 & 20 & 16 & 13 & 11 & 9 & 8 & 7 & 6 \\
$\mathbf{0 . 9}$ & 1702 & 425 & 189 & 106 & 68 & 47 & 35 & 27 & 21 & 17 & 14 & 12 & 10 & 9 & 8 \\
$\mathbf{0 . 9 5}$ & 2401 & 600 & 267 & 150 & $\mathbf{9 6}$ & 67 & 49 & 38 & 30 & 24 & 20 & 17 & 14 & 12 & 11 \\
$\mathbf{0 . 9 7}$ & 2970 & 743 & 330 & 186 & 119 & 83 & 61 & 46 & 37 & 30 & 25 & 21 & 18 & 15 & 13 \\
$\mathbf{0 . 9 9}$ & 4160 & 1040 & 462 & 260 & 166 & 116 & 85 & 65 & 51 & 42 & 34 & 29 & 25 & 21 & 18 \\
$\mathbf{0 . 9 9 7 3}$ & 5625 & 1406 & 625 & 352 & 225 & 156 & 115 & 88 & 69 & 56 & 46 & 39 & 33 & 29 & 25 \\
\hline
\end{tabular}

To ensure the necessary qualifications of experts on this issue, requests were made to the organization where the employees included in the National Register of Specialists (SRS) work. The total number of experts was divided into 5 groups (20 people in each), taking part in the survey together. The experts had to provide the average terms (in days) for the implementation of the presented stages of the investment and construction project, based on the experience in the construction of such facilities. The experts had to evaluate: development and evaluation of the business plan of the investment project; preparation of administrative documents; holding a tender for the selection of designers; development of initial permits and design documentation; examination of project documentation; obtaining a building permit; holding a tender for the selection of a general contractor; development of detail documentation, construction of an object; state expertise of the object; obtaining an opinion on compliance; putting the facility into operation.

\section{Results and Discussion}

Many specialists agree that the deployment of a single information cluster will improve the 


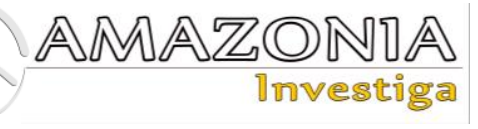

interaction of construction organizations with each other and state construction supervision bodies, which will contribute to the gradual integration between all market participants (Bond and MacLeod, 2001; Choi et al., 2018; Vernadat, 2020; Santos et al., 2017). And more than 93 thousand such participants are registered in Russia, according to the unified register of the National Association of Builders. Also, more than 211 thousand specialists are registered in the National Register of Specialists (NRS). Any participant in a certain construction process must have up-to-date information on the actual performance of work in real-time (online). An automated mechanism will generate documentation without wasting time and create a timely document flow between all participants in the construction. The system will also allow choosing the implementation method (large local project, consistent project implementation, simultaneous implementation of several projects); choose a form of strategic engineering infrastructure management (a set of measures interrelated in terms of resources, terms, and counterparties), create a strategic management mechanism for specific conditions (Olugboyega et al., 2020; Olbina and Elliott, 2019).
From the author's point of view, the Unified Information Platform is impossible without the use of big data: multidimensional data, large data, and data with incomplete information (models with uncertainty). All these special cases of big data are used for visualization. The Unified Information Platform uses computer graphics hardware and software as "large screens" and virtual reality environments (Shneiderman, 2014). Their features: great flexibility in working with 3D fractals, working with lighting by shadows, color; support for ambient occlusion effects (based on tracking multiple rays), depth of field, unlimited image resolution on 64-bit systems, etc. Analysis and modeling of user behavior, assessment, and measurement of the quality of visual and interactive systems, verification and validation of visualization are also included in the platform (Cao et al., 2019). With the help of visual analytics, the description and presentation of abstract information obtained resulted from the process of collecting and processing multicategory data, for the analysis of which, it was necessary to apply several quantitative and qualitative assessment measures (Maletic et al., 2002). Fig. 4 shows the framework of big data processing.

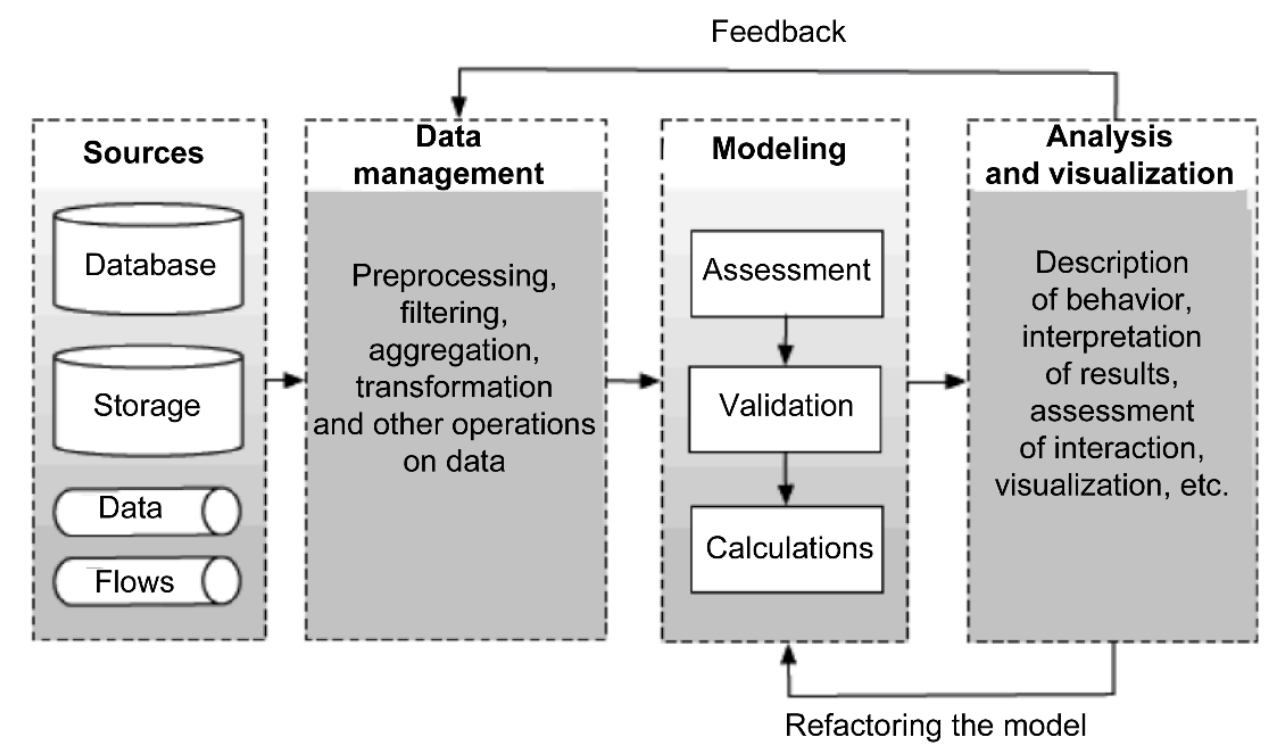

Figure 4. Big data processing framework. Source: the autor.

Ultimately, all this will make it possible to draw up a unified construction schedule. The technical customer will be able to predict his financial model with a high degree of accuracy (financial costs, commissioning of the facility, payback of the facility), the general contractor will be able to accurately plan material and labor resources in the process of work, minimize warehouse stocks, devote more time to the quality of work, without being distracted by the completion of documentation, as well as plan your interaction with other subcontractors while keeping the number of meetings to a minimum number (Fig. 5). 


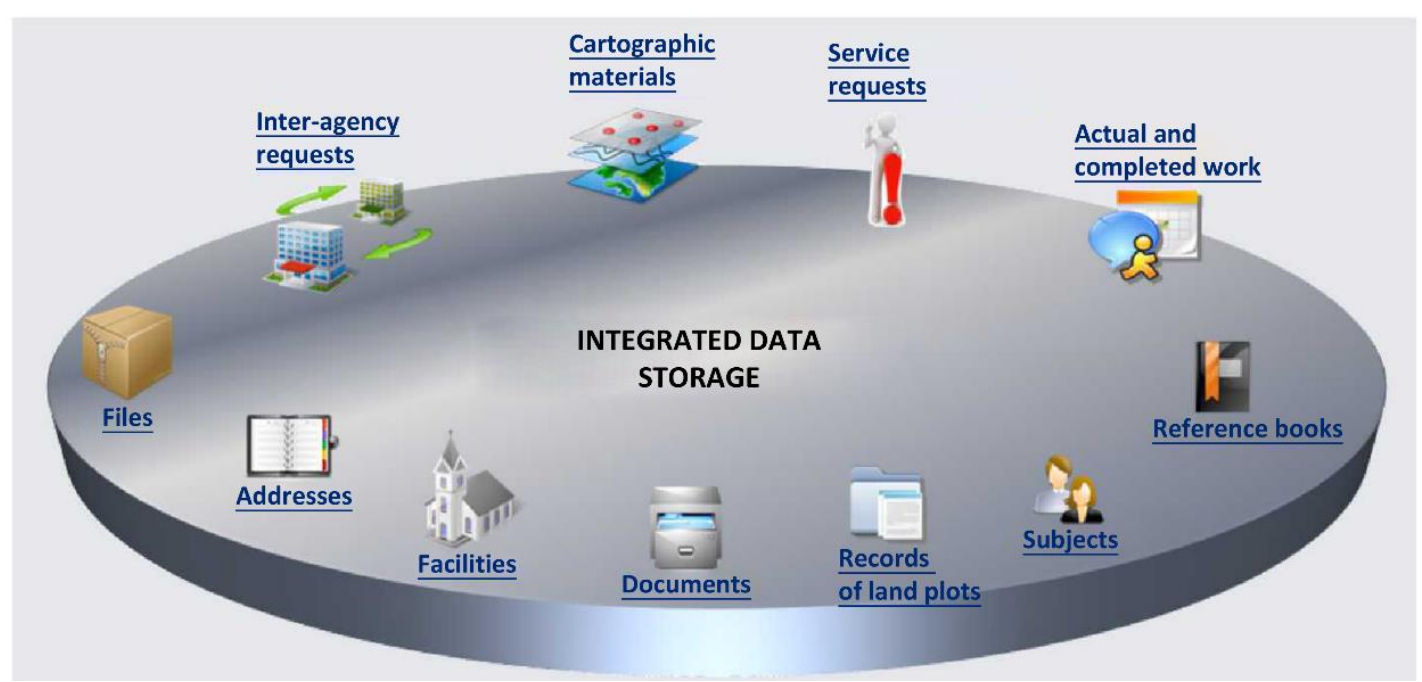

Figure 5. State information system for urban planning activities. Source: the autor.

The construction industry differs from other sectors of the national economy in some specific features. The uncertainty of the final result in terms of time, cost, and quality takes a special place. This is determined by the fact that some external and internal factors influence the implementation of such projects. One of these factors is the interaction of participants in urban planning activities to implement housing investment and construction projects. The main effect of improving interactions will be an increase in productivity and a reduction in construction time with sufficient quality, which is an urgent task for market participants in implementing any housing construction project. Based on the study of a very significant array of scientific research and developments of Russian and foreign specialists in the field of digitalization of the construction industry (Petrov and Larionov, 2020; Smirnova and Larionov, 2020; Smirnova et al., 2020), the authors came to the following results from the introduction of the Unified Information Platform (UIP).

The author has developed the following thematic categorization or classification of multi-parameter problems:

1) Registration on the platform. When registering, the user fills in all the data about him.
2) Accreditation system. Administrators of the UIP will carry out user verification through integration with the main systems and data from the unified registers of self-regulatory organizations (SRO), the National Association of Surveyors and Designers (NOPRIZ), the National Association of Builders (NOSTROY). Verification will not be possible for users who are not included in the registries or who had a "bad reputation".

3) Personalization via Face ID + electronic digital signature (EDS). All accredited users will have to bind their EDS to Face ID. Thus, it will always be possible to prove or invalidate this user who used his EDS. This will provide personal responsibility on the platform and identification when logging into the system.

4) Distribution of users to the corresponding databases of construction participants. For the convenience of work, all users of the UIP will be distributed to the appropriate databases that can interact with each other.

5) Creation of a personal account. Each participant in the construction process will have their account. Depending on which base the user is included in, he will receive his own set of functions. The distribution scheme of users is shown in Fig. 6. 


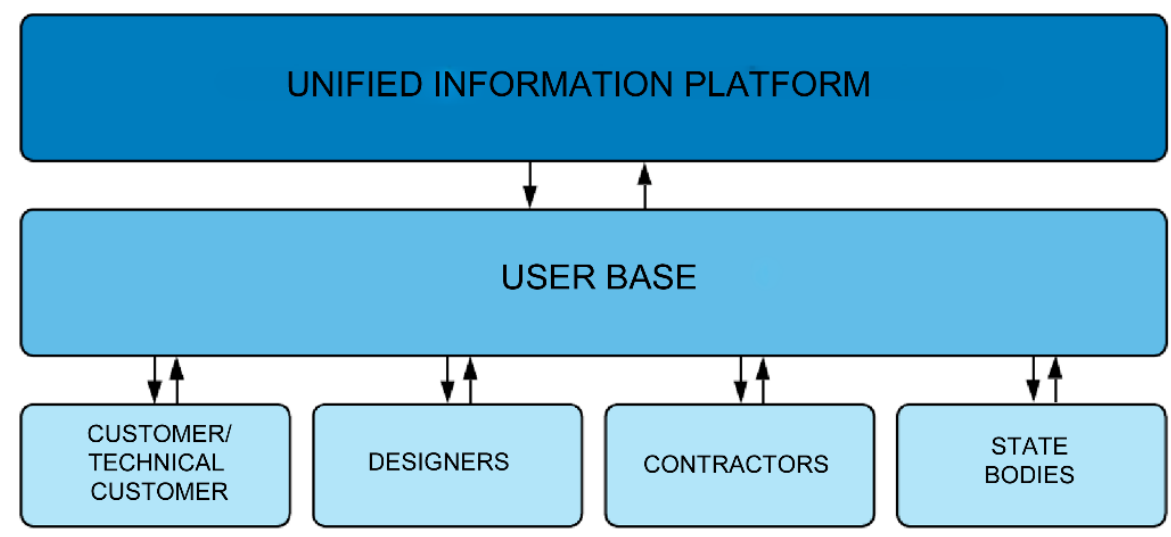

Figure 6. User distribution block diagram. Source: the autor.

The following are modular solutions for the relationship between users of the Unified Information Platform:

1) The "Tender" module serves for a quick and reasonable search for contractors and subcontractors, taking into account such criteria as the geography of their work, experience in performing the required work and the history of previously concluded contracts.

2) "Design" is intended for interaction according to the "Customer/Technical Customer Designer" scheme. The main task of the second module is to provide up-to-date information to the Customer/Technical Customer on the implementation of design or detail documentation, as well as monitoring the release of design and detail documentation.

3) "Construction", this module is aimed at the implementation of interaction according to the scheme "Customer/Technical Customer General Contractor". The main task of the third module is to provide up-to-date information to all participants in the construction (i.e., data on facility readiness, backlog, cost of work).

4) "Control", this module is configured to implement interaction according to the scheme "Customer/Technical Customer Construction control - Contractor" and will unite the Customer, Contractor, Technical and Architectural Supervision. Among the tasks of the module are the following: timely construction control over the quality of construction and installation works; verification of construction technology and compliance with regulatory documents and rules; verification of the facility under construction for compliance with the technical requirements of the customer and working design documentation (including volumes and deadlines).

5) "State", this module involves the interaction of participants in housing construction, nonprofit organizations such as SRO, NOPRIZ, NOSTROY, as well as state bodies: state construction supervision (GOS) and state expertise. The platform provides access to state information systems for urban planning (GISOGD).

For the classification of modular data, the titanic workflow must be implemented by the following means: data filtering, which assumes obtaining the necessary information in a minimum time; slicing (a special case of filtering), brushing - interactive painting of data with color; data clustering based on the Map-Reduce algorithm; implementation of the data flow model; algorithms with external memory, minimizing the overhead of I/O disk; autonomous computing; self-configuration, selfoptimization, self-restoration, self-defense. A wide range of parameters for configuring the adaptive interface of the information system will ensure quality, accurate timing and minimize the cost of the construction object. The UIP will be able to prevent the root causes of emerging problems, such as coordination errors, ineffective organization of inspections, and the loss of information about defects, which leads to late management response.

The survey results demonstrate the different duration of each stage of the project when using different methods of interaction between the participants in urban planning (Fig. 7). 


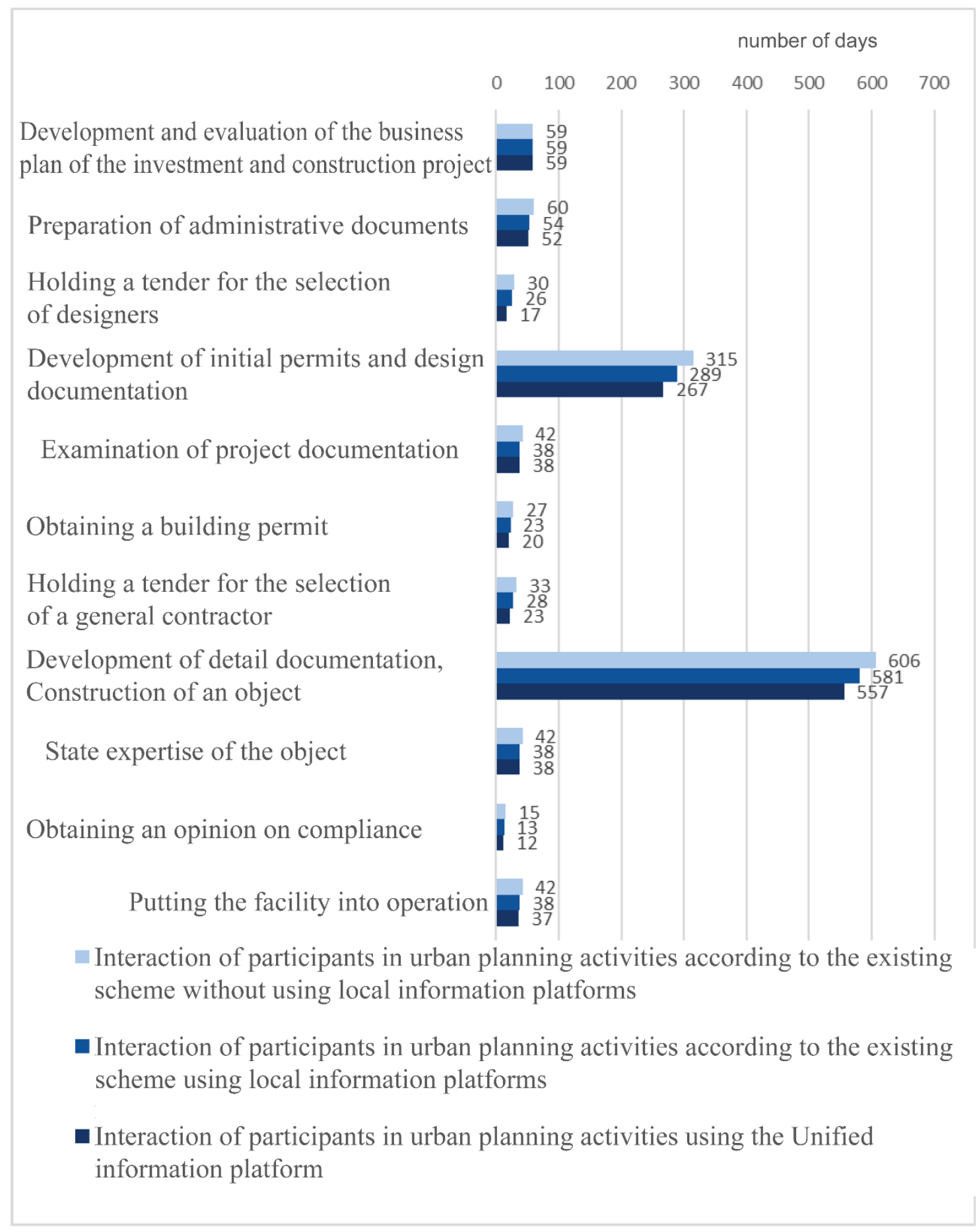

Figure 7. Duration of implementation of each stage of the project. Source: the autor.

A comparison of the terms of the project is presented in Table 2. 
Table 2.

Terms of implementation of an investment and construction project, depending on the interaction of participants in urban planning activities (without using information platforms, using local information platforms, using the Unified Information Platform). Source: the author.

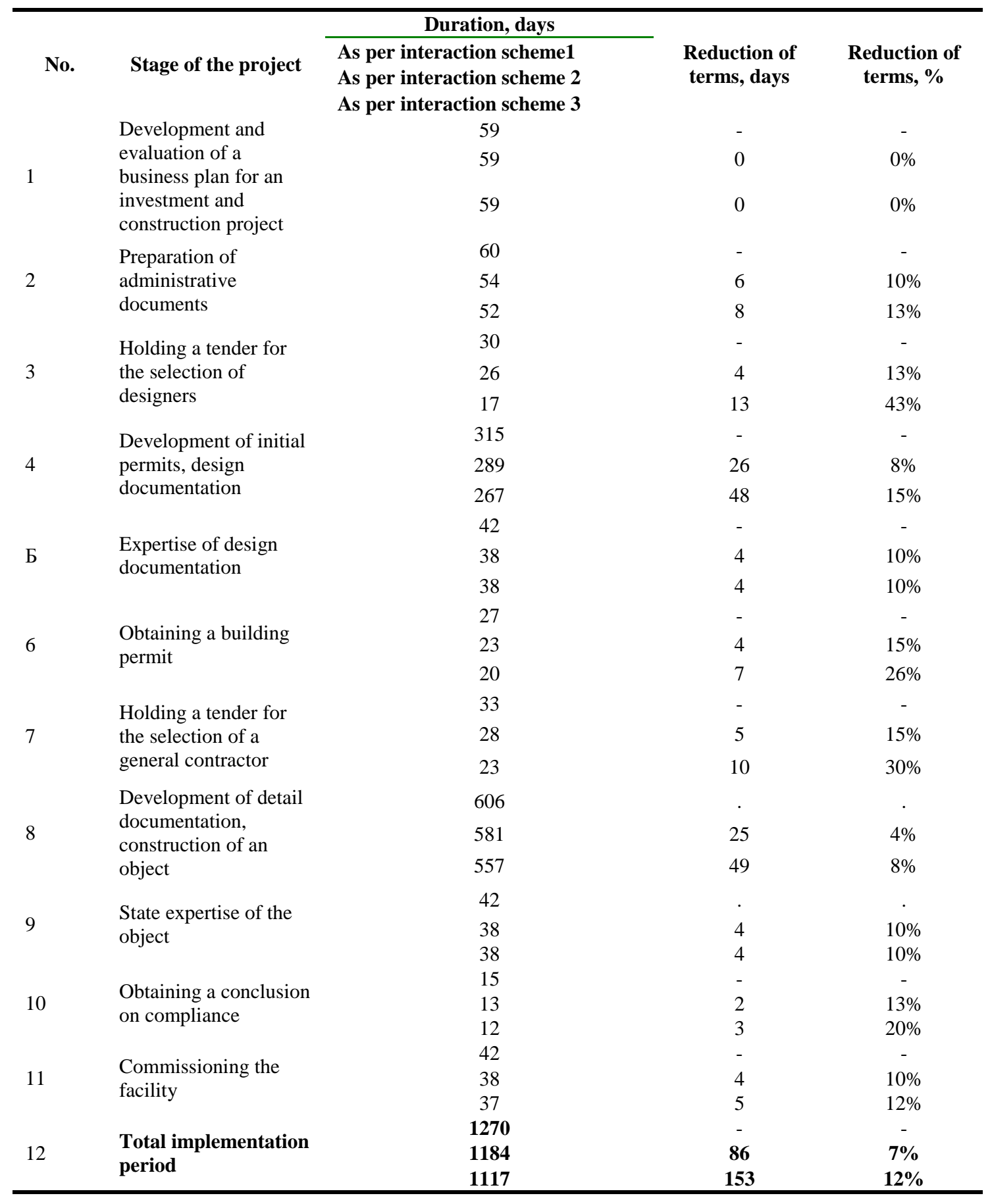

The presented comparison shows that the implementation of the UIP will reduce the time frame for the implementation of the construction project at certain stages by $43 \%$ (position 3 holding a tender for the selection of designers). The total construction period of the facility can be reduced by 153 days (12\%). Thus, the interaction of participants in urban planning activities according to the existing scheme using local information platforms reduces the total duration of the construction project by $7 \%$, which is a lot. A $12 \%$ reduction from the implementation of the UIP will undoubtedly facilitate a significant reduction in the cost of construction work. 


\section{Conclusions}

All particular and specific projects of the engineering infrastructure of Moscow and the Moscow Region, included in the information field of the Unified Digital Platform, demonstrate the features of a single social project implemented in the interests of the entire Russian society. Their features: large-scale implementation; an integral part of the social development strategy; leading role concerning other elements of planned events and actions; comprehensive and inclusive origin; relevance for all functions of the urban area; comprehensive financial and management support. The implementation of the Unified Information Project will have a beneficial effect on the development of separate regions and the country as a whole.

The introduction of a unified information system makes it possible, through electronic interaction, to control the venal interests of corporations and not allow subjugating the techno-structure represented by government officials.

Finally, the use of information technologies guarantees maximum efficiency and productivity while minimizing production costs.

\section{Bibliographic references}

Agstner, P., \& Mascheroni, D.M. (2020). Breach of the mandatory bid rule: minority shareholders' protection in the public vs. private enforcement debate. European Company and Financial Law Review, 17(6), 726-759.

Aguilera, R.V. (2005). Corporate governance and director accountability: An institutional comparative perspective. British Journal of Management, 16(SI), S39-S53.

Ajan, R.S. (ed.) (2003). Sustaining Competitiveness in The New Global Economy: The Experience of Singapore. Cheltenham, UK: Edward Elgar Pub.

Altman, M. (1999). The methodology of economics and the survival principle revisited and revised: Some welfare and public policy implications of modeling the economic agent. Review of Social Economy, 57(4), 427-449.

Altman, M. (2017). Policy consequences of multiple equilibria and the indeterminacy of economic outcomes in a boundedly rational world: Closing the system with non-economic variables. Forum for Social Economics, 46(3), 234-251.

Ansoff, H.I. (1977). State of practice in planning systems. Sloan Management Review, 18(2), $1-24$.
Ansoff, H.I. (1980). Strategic issue management. Strategic Management Journal, 1(2), 131-148.

Ansoff, H.I. (1985). Conceptual underpinnings of systematic strategic management. European Journal of Operational Research, 19(1), 2-19.

Ansoff, H.I. (1987). The emerging paradigm of strategic behavior. Strategic Management Journal, 8(6), 501-515.

Ansoff, H.I. (1995). Corporate Strategy: An Analytical Approach to Business Policy for Growth and Expansion. New York: McGrawHill.

Ansoff, H.I. (2007). Strategic Management. Houndmills, UK: Palgrave Macmillan.

Bernhagen, P. (2007). The Political Power of Business: Structure and Information in Public Policymaking (Series: Routledge Research in Comparative Politics, vol. 21). London; New York: Routledge.

Bond, A.J., \& MacLeod, I.A. (2001). A strategy for computer modeling in geotechnical design. Proceedings of the ICE - Geotechnical Engineering, 149(2), 95-102.

Cao, X., Wang, M., \& Liu, X. (2019). Application of Big Data visualization in urban planning. IOP Conference Series-Earth and Environmental Science, 440(1), 042066.

Choi, Jiyong, Leite, F., \& de Oliveira, D.P. (2018). BIM-based benchmarking system for healthcare projects: Feasibility study and functional requirements. Automation in Construction, 96, 262-279.

Ciscel, D.H. (1984). Galbraith's planning system as a substitute for market. Journal of Economic Issues, 18(2), 411-418.

Ciscel, D.H. (2001). The economics of urban sprawl: Inefficiency as a core feature of metropolitan growth. Journal of Economic Issues, 2(35), 405-413.

Ciscel, D.H., \& Smith, B.E. (2005). The impact of supply chain management on labor standards: The transition to incessant work. Journal of Economic Issues, 39(2), 429-437.

Claassen, R.J.G. (2021). Hobbes meets the modern business corporation. Polity, 53(1), 101-131.

Dickinson, H.D. (1971). Economics of Socialism. New York: Books for Libraries Press. Galbraith, J. (1988). Economics and The Public Purpose. New York: New American Library. Galbraith, J. (1997). The Age of Uncertainty. Boston: Houghton Mifflin.

Gary, M.S., Yang, M.M., Yetton, P.W., \& Sterman, J.D. (2017). Stretch goals and the distribution of organizational performance. Organization Science, 28(3), 395-410.

Gray, C.F., \& Larson, E.W. (2008). Project management: The Managerial Process 


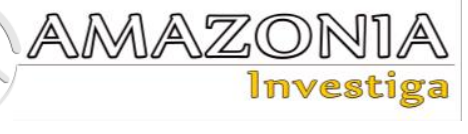

(McGraw-Hill/Irwin Series Operations and Decision Sciences). Boston: McGraw-Hill/Irwin. Hernandez, E., \& Menon, A. (2021). Corporate strategy and network change. Academy of Management Review, 46(1), 80-107.

Huovinen, P. (2019). Advancing networkingbased business management in construction markets. In 10th Nordic Conference on Construction Economics and Organizatio (Emerald Reach Proceedings Series, Vol. 2). Lill, I. \& Witt, E. (eds.), (pp: 41-47). Bingley, UK: Emerald Publishing.

Lambin, J-J., Chumpitaz, R., \& Schuiling, I. (2007). Market-driven Management: Strategic and Operational Marketing. New York: Palgrave MacMillan, Basingstoke.

Lerner, A.P. (1970). The Economics of Control: Principles of Welfare Economics. New York, NY: Kelley.

Lieberman, M., \& Hall, R. (2000). Introduction to Economics. Cincinnati: South Western College Pub.

Lo, F.Y, \& Liao, P.Ch. (2021). Rethinking financial performance and corporate sustainability: Perspectives on resources and strategies. Technological Forecasting and Social Change, 162, 120346.

Maletic, J.I., Marcus, A., \& Collard, M.L. (2002). A task oriented view of software visualization. In Proceedings of 1st International Workshop on Visualizing Software for Understanding and Analysis (VISSOFT 2002), Paris, France, (pp: 32-40). Paris: IEEE Computer Soc.

McWilliams, A., \& Siegel, D. (2001). Corporate social responsibility: A theory of the firm perspective. Academy of Management Review, 26(1), 117-127.

Olbina, S., \& Elliott, J.W. (2019). Contributing project characteristics and realized benefits of successful BIM implementation: A comparison of complex and simple buildings. Buildings, $9(8), 175$.

Olugboyega, O., Edwards, D.J., Windapo, A.O., Omopariola, E.D., \& Martek, I. (2020). Development of a conceptual model for evaluating the success of BIM-based construction projects. Smart and Sustainable Built Environment, DOI: 10.1108/SASBE-022020-0013

Ottaviano, E., Pelliccio, A., Gattulli, V. (eds.) (2018). Mechatronics for Cultural Heritage and Civil Engineering. Cham: Springer.

Petrov, A., \& Larionov, A. (2020). Organizational and economic aspects of managing St Petersburg's (Russia) strategic plan dynamic model. Espasios, 41(10), 21.

Pigou, A. (1999). Employment and Equilibrium. Basingstoke: Macmillan.
Reinhardt, F.L., \& Stavins, R.N. (2010). Corporate social responsibility, business strategy, and the environment. Oxford Review of Economic Policy, 26(2), 164-181.

Reinhardt, F.L., Stavins, R.N., \& Vietor, R.H. (2008). Corporate social responsibility through an economic lens. Review of Environmental Economics and Policy, 2(2), 219-239.

Santos, R., Costa, A.A., \& Grilo, A. (2017). Bibliometric analysis and review of Building Information Modelling literature published between 2005 and 2015. Automation in Construction, 80, 118-136.

Schumpeter, J. (2019). American institutions and economic progress. Scienza \& Politica - Per una storia delle dottrine, 31(61), 171-183.

Schumpeter, J., Becker, M. C., \& Knudsen, T. (2002). The fundamental phenomenon of economic development. American Journal of Economics and Sociology, 61(2), 405-437.

Schumpeter, J.A. (2013). Capitalism, Socialism, and Democracy. London: Routledge.

Shneiderman, B. (2014). The big picture for big data: Visualization. Science, 343(6172), 730.

Smirnova, E. (2020). Environmental risk analysis in construction under uncertainty. In Reconstruction and Restoration of Architectural Heritage. Sementsov, S., Leontyev, A., Huerta, S., Menéndez Pidal de Nava, I. (eds.), (pp. 222-227). London: CRC Press.

Smirnova, E. (2021). Monte Carlo simulation of environmental risks of technogenic impact. In Contemporary Problems of Architecture and Construction. Rybnov, E., Akimov, P., Khalvashi, M., Vardanyan, E. (eds.), (pp: 355-360). London: CRC Press.

Smirnova, E., \& Larionov, A. (2020). Justification of environmental safety criteria in the context of sustainable development of the construction sector. E3S Web of Conferences 157, 06011.

Smirnova, E., Larionova, Y., \& Larionov, A. (2020). Sewer system optimization in housing and communal services. E3S Web of Conferences, 157, 02002.

Sterman, J.D. (2000). Business Dynamics: Systems Thinking and Modeling for a Complex World. Boston: Irwin McGraw-Hill.

Stockhammer, E. (2006). Uncertainty, class, and power. Journal of Political Economy, 35, 31-49. Szostak, B.L., \& Boughzala, Y. (2021). The role of design thinking in corporate social responsibility (CSR) strategy and its influence on innovation. Journal of Innovation Economics \& Management, 34, 169-195.

Tolstenko, A., Baltovskij, L., \& Radikov, I. (2019). Chance of civic education in Russia. Sage Open, 9(3), 1-16. 
Vernadat, F. (2020). Enterprise modelling: Research review and outlook. Computers in Industry, 122, 103265.

Voronkova, V.H., Nikitenko, V.A., \& Teslenko, T.V., Bilohur, E.V. (2020). Impact of the worldwide trends on the development of the digital economy. Amazonia Investiga, 9(32), 81-90,

https://amazoniainvestiga.info/index.php/amazo nia/article/view/1478 